ISSN 1392-3196 / e-ISSN 2335-8947

Zemdirbyste-Agriculture, vol. 102, No. 2 (2015), p. 177-184

DOI $10.13080 / \mathrm{z}-\mathrm{a} .2015 .102 .023$

\title{
Characterization of strawberry (Fragaria $\times$ ananassa Duch.) cultivars and hybrid clones using SSR and AFLP markers
}

\author{
Rytis RUGIENIUS ${ }^{1}$, Jūratė Bronė ŠIKŠNIANIENE ${ }^{1}$, Birutė FRERCKS ${ }^{1}$, Gražina STANIENĖ ${ }^{1}$, \\ Inga STEPULAITIENE ${ }^{1}$, Perttu HAIMI ${ }^{1}$, Vidmantas STANYS ${ }^{1,2}$ \\ ${ }^{1}$ Institute of Horticulture, Lithuanian Research Centre for Agriculture and Forestry \\ Kauno 30, Babtai, Kaunas distr., Lithuania \\ E-mail: r.rugienius@1sdi.lt \\ ${ }^{2}$ Aleksandras Stulginskis University \\ Studentų 11, Akademija, Kaunas distr., Lithuania
}

\begin{abstract}
Simple sequence repeat (SSR) and amplified fragment length polymorphism (AFLP) markers are commonly used in genetics and breeding studies due to their multi-allelic nature, high abundance, reproducibility, transferability over genotypes and extensive genome coverage. The genetic characterization of 44 strawberry (Fragaria $\times$ ananassa Duch.) genotypes using SSR and AFLP markers is presented in the study. The genetic diversity of strawberry cultivars and hybrid clones developed mostly at the Institute of Horticulture of Lithuanian Research Centre for Agriculture and Forestry's breeding programme was evaluated using 11 previously published SSR primer pairs and 6 AFLP primer combinations. Nine to 21 alleles per primer pair were identified in the SSR multiplex analysis. The number of differentiated genotypes varied between 12 and 38. The microsatellite primer pairs ARSFL-009, CFACT152 and EMFv104 were the most informative. The number of polymorphic fragments in the AFLP study varied between 44 and 197. The rate of polymorphism varied from 39\% (primer combination EcoRI-AGG/MseICAA) to $88 \%$ (EcoRI-ACC/MseI-CAC). The results in this study demonstrated that the chosen previously published SSR primer pairs and the selected AFLP primer combinations after pre-screening procedure were suitable for the genotyping of strawberry accessions. For the cluster analysis fragments of both marker systems were used to get a more comprehensive description of the genetic relationships of the evaluated strawberry accessions. The cluster analysis revealed two main groups consisting of 10 and 34 strawberry cultivars and clones, respectively.
\end{abstract}

Key words: amplified fragment length polymorphism, genetic diversity, genotyping, hybrids, simple sequence repeat, strawberry.

\section{Introduction}

Commercially important strawberries (Fragaria $\times$ ananassa Duch.) belong to the family Rosaceae and the genus Fragaria, which comprises 23 species (RousseauGueutin et al., 2009). With its high nutritional value, the strawberry is one of the most popular berry fruits in the world. The cultivated strawberry, $F \times \times$ ananassa, is an octoploid $(2 \mathrm{n}=8 \mathrm{x}=56)$. Cultivated strawberry arises from a narrow genetic base of approximately 50 founding clones (Dale, Sjulin, 1990). Because of this, it is difficult to effectively breed new varieties with differing genetic characteristics. Marker-assisted selection, with the help of polymorphic markers may be of benefit (Yoon et al., 2012). It allows clarifying the level of genetic divergence among strawberry genotypes.

Many biochemical and molecular marker systems have been used for strawberry cultivar identification, including isozymes (Bell, Simpson, 1994), randomly amplified polymorphic DNA (RAPD) (Milella

et al., 2006), amplified fragment length polymorphism (AFLP) (Degani et al., 2001), inter simple sequence repeat (ISSR) (Arnau et al., 2002) and simple sequence repeat (SSR) markers (Lewers et al., 2005; Gil-Ariza et al., 2006; Govan et al., 2008; Sargent et al., 2008). Each of these systems has their own technical limitations. While microsatellites exhibit co-dominant inheritance, RAPD and AFLP markers are usually dominant (Brunings et al., 2010).

SSR markers have been employed extensively in strawberry because of their reproducibility and ability to sensitively detect subtle polymorphisms. Application of this technology to strawberry is particularly difficult because strawberries are octoploid, with eight copies of each gene, and because inbreeding can lead to cultivars with multiple copies of the same allele at a single locus. Dangl et al. (2007) described an SSR marker system that can distinguish closely related strawberry cultivars. This 
system uses published markers to reduce development time, and scores the amplified fragments as dominant markers. Because primer binding is highly specific, this system is both highly accurate and reproducible by other laboratories.

AFLP are highly reproducible dominant markers (Agarwal et al., 2008) and the large number of fragments gives them high statistical power (Meudt, Clarke, 2007). Therefore, AFLP markers are well suited for distinguishing between closely related genotypes.

Both marker systems have pros and cons. On the one hand, SSR markers are highly specific, due to their development from already known DNA sequences. Their usefulness was shown in our previous works on other Rosacea family plants - Prunus avium (Stanys et al., 2012) and Pyrus communis (Rugienius et al., 2013), but the number of markers (fragments) is limited and they cover mostly just the non-coding DNA regions. On the other hand, AFLP markers do not require the primary knowledge about the DNA sequences, the high number of fragments is generated with one primer combination and they cover whole genome, but they need the prescreening option for the selection of highly polymorphic primer combinations for the object to be examined (Frercks et al., 2013; 2014).

The breeding program of strawberry in Lithuania started in the middle of the last century. New cultivars, resistant to cold and fungal diseases, with varying season of ripening and high productivity were introduced (Rugienius et al., 2004; Baniulis et al., 2013). To successfully implement a breeding program, it is essential to characterize the available germplasm, both by assessment of plant morphological traits and by molecular methods. Germplasm characterization by DNA-based molecular markers allows determination of the level of genetic divergence and the molecular pattern of each cultivar. With this data, the breeder can plan crosses using molecular and field data, which can result in the development of superior cultivars more quickly and economically (Lörz, Wenzel, 2005).

Therefore, the aim of our study was to assess the genetic diversity of 44 genotypes of Lithuanian and introduced strawberry cultivars and their genetic relationships using SSR and AFLP molecular markers. The informativeness of the both marker systems for the identification of genotypes used in this study was assessed.

\section{Materials and methods}

Plant material. Forty four strawberry (Fragaria $\times$ ananassa Duch.) accessions, including twenty four hybrid clones, developed at the Institute of Horticulture of Lithuanian Research Centre for Agriculture and Forestry's breeding programme: two Lithuanian strawberry cultivars 'Venta' and 'Saulenè', one somatic variant of cv. 'Venta' ('Venta Rvk') and seventeen cultivars and hybrids of European origin were used in the study (Table 1). Plant material was sampled during 2013-2014 in the collection of strawberry genetic resources at the Institute of Horticulture of Lithuanian Research Centre for Agriculture and Forestry.

Deoxyribonucleic acid (DNA) extraction. DNA was extracted from leaves using CTAB (cetyltrimethylammonium bromide) method (Doyle, Doyle, 1990). Genomic DNA was stored in TE buffer $(100 \mathrm{mM}$ Tris-HCl, $10 \mathrm{mM}$ EDTA and $\mathrm{pH}-8)$ at $-20^{\circ} \mathrm{C}$. DNA concentration was measured using a nanophotometer P 300 (Implen GmbH, Germany).

Simple sequence repeat (SSR) analysis. Eleven previously published primer pairs were used for SSR analysis: ARSFL-009, -010, -011 (Lewers et al., 2005), EMFv-125, -104 (Sargent et al., 2006), EMFax-380097, -381827, and CFACT-084, -110, -103, -152 (Sargent et al., 2008). The multiplex PCR (polymerase chain reaction) were performed according to Yoon et al. (2012) for primers ARSFL-009, -010, -011 and for remaining eight primers according to Dangl et al. (2007). SSR analyses were repeated at least twice on all samples in order to check the reproducibility of the data. Fragment analysis was performed using a capillary electrophoresis instrument Genetic Analyser 3130 (Thermo Fisher Scientific Inc., USA).

Amplified fragment length polymorphism (AFLP) analysis. Isolated genomic DNA (10 ng) was cut by EcoRI and Tru1I (MseI) restriction enzymes (Thermo Fisher Scientific Baltics, Lithuania) and ligated with EcoRI and MseI DNA adapters, using T4 DNA ligase. AFLP samples were prepared using AFLP pre selective primer mix for regular plant genomes (Thermo Fisher Scientific Inc.). The PCR conditions for pre selective and selective amplification were performed according to Vos et al. (1995) with some modifications. The six primer combinations used were E-ACT/M-CAC, E-AGG/MCAA, E-ACC/M-CAT, E-ACC/M-CTA, E-ACC/M-CAC and E-ACC/M-CAG. Fragment analysis was performed using a Genetic Analyser 3130 (Thermo Fisher Scientific Inc.). Standard GeneScan 500 LIZ was used for capillary electrophoresis. AFLP analyses were repeated at least twice on all samples in order to check reproducibility of the data.

Data analysis. Data from SSR and AFLP methods was analysed using software GeneMapper v.4.0 (Thermo Fisher Scientific Inc.) and converted to binary matrix to compare both methods and to create the common (SSR with AFLP markers) dendrogram. The dendrogram combining data of SSR and AFLP markers was performed on software Treecon v.1.3b (Van de Peer, De Wachter, 1994), using Nei and Li distance and UPGMA (unweighted pair group method with arithmetic mean) methods within this software. To test the reliability of the dendrograms, a bootstrap analysis with 1000 replications was performed within software Treecon. Only the bootstrap values $\geq 50 \%$ (the threshold of the greatest lower bound of reliability) were indicated on the dendrogram according to Hall (2008). 
Table 1. Pedigree of strawberry cultivars and hybrid clones

\begin{tabular}{|c|c|c|c|}
\hline No. & Cultivar or hybrid clone & Pedigree & Origin \\
\hline 1. & 'Antea' & FB6L-3 × 'Onebor' & Italy \\
\hline 2. & ‘Ariel’' & Unknown & Italy \\
\hline 3. & 'Asia' & Unknown & Italy \\
\hline 4. & 'Chelsea Pensioner' & UK and Italian selections & United Kingdom \\
\hline 5. & 'Darselect' & 'Parker' × 'Elsanta' & France \\
\hline 6. & 'Elegance' & EM834 × EM1033 & United Kingdom \\
\hline 7. & 'Elkat' & 'Elsanta' $\times$ 'Dukat' & Poland \\
\hline 8. & 'Figaro' & 'Elsanta' $\times$ 'Pajaro' & Netherlands \\
\hline 9. & 'Gava’' & Unknown & Italy \\
\hline 10. & ‘Lucy’ & 'Honeoye', 'Selva', 'Rapella' & United Kingdom \\
\hline 11. & 'Orleans' & 'L'Acadie' × 'Joliette' & Canada \\
\hline 12. & 'Rubinovyj kulon' & 'Senga Sengana' × 'Fairfax' & Russia \\
\hline 13. & 'Sara' & 'Senga Sengana', Fragaria vesca & Sweden \\
\hline 14. & 'Saulenè' & 'Senga Sengana' × 'Shuksan’ & Lithuania \\
\hline 15. & 'Valotar' & 'Jewell' × ‘Senga Sengana' & Finland \\
\hline 16. & 'Venta' & 'Senga Sengana' $\times$ 'Festivalnaja' & Lithuania \\
\hline 17. & 'Venta Rvk' & 'Venta' & Lithuania \\
\hline 18. & 'Zumba' & Unknown & Netherlands \\
\hline 19. & L-181 & Unknown & Italy \\
\hline 20. & J973854 & K88-4 × 'Mohawk' & Canada \\
\hline 21. & 940101 & 'Guardian' × 'Pegasus' & Lithuania \\
\hline 22. & 051901 & 'Sophia' × 'Arosa' & Lithuania \\
\hline 23. & 000206 & 'Anapolis' $\times$ 'Polka' & Lithuania \\
\hline 24. & 080801 & 'Venta' × 'Irma' & Lithuania \\
\hline 25. & 080901 & 'Venta' $\times$ 'Ariel' & Lithuania \\
\hline 26. & 080903 & 'Venta' $\times$ 'Ariel' & Lithuania \\
\hline 27. & 080904 & 'Venta' $\times$ 'Ariel' & Lithuania \\
\hline 28. & 082901 & 'Irma' × 'Salut' & Lithuania \\
\hline 29. & 083101 & 'Marmolada' $\times$ 'Pink Panda' & Lithuania \\
\hline 30. & 084308 & 'Venta' × 'Roxana' & Lithuania \\
\hline 31. & 084309 & 'Venta' × 'Roxana' & Lithuania \\
\hline 32. & 102101 & ‘Ariel' × ‘Jonsok’ & Lithuania \\
\hline 33. & 102201 & 'Fenella' $\times$ 'Festivalnaja' & Lithuania \\
\hline 34. & 102401 & 'Fenella' × 'Orleans' & Lithuania \\
\hline 35. & 102601 & 'Sonata' × 'Festivalnaja' & Lithuania \\
\hline 36. & 103001 & 'Elegance' × 'Rubinovyj kulon' & Lithuania \\
\hline 37. & 103301 & 'Lucy' × 'Festivalnaja' & Lithuania \\
\hline 38. & 103701 & $98.167 .1 \times$ ×Jonsok’ & Lithuania \\
\hline 39. & 103801 & L-181 × 'Jonsok’ & Lithuania \\
\hline 40. & 104001 & 'Asia' $\times$ 'Desnianka' & Lithuania \\
\hline 41. & 104002 & 'Asia' $\times$ 'Desnianka' & Lithuania \\
\hline 42. & 104601 & 'Salut' $\times$ 'Elsanta' & Lithuania \\
\hline 43. & 104701 & 'Darselect' open pollinated & Lithuania \\
\hline 44. & 005042 & 'Selen' $\times 952020($ 'Tribute' $\times F$. chiloensis $)$ & Lithuania \\
\hline
\end{tabular}

\section{Results and discussion}

SSR analysis. A total of 181 polymorphic alleles were identified for 44 Fragaria accessions using 11 SSR primer pairs. The results from the 11 SSR primer pairs are summarized in Table 2. The allele size ranged from $71 \mathrm{bp} \mathrm{(EMFv-104)} \mathrm{to} 288 \mathrm{bp}$ (ARSFL-011). The number of alleles per primer pair varied from 9 (CFACT-103) to 21 (EMFv-104), with an average of 16.5 alleles per SSR primer pair. The highest number of alleles (21) was obtained with the EMFv-104 primer pair. This primer pair was also the most informative by Honjo et al. (2011). According to the number of alleles in this study, the primer pairs ARSFL-009 (20), ARFSL-010 (16) and ARFSL-011 (17) were highly informative also and the number of obtained alleles was higher as compared to the studies of Dangl et al. (2007) and Brunings et al. (2010), where 26 and 45 genotypes were investigated, 
respectively. Primer pair CFACT-110 was also one of the most informative ones according to one of the highest number of alleles in our study and the study of Yoon et al. (2012) as well.

Primer pairs used in this study were able to distinguish between 12 and 38 of 44 strawberry genotypes (Table 2). According to the number of differentiated genotypes, the most informative primer pairs were ARSFL-009 and CFACT-152. Dangl et al. (2007) suggested using the primer ARSFL-009, followed by primers ARSFL-010 and ARSFL-011 for cultivar identification according to their highest number of alleles and unique peak profiles. The primer pair EMFv104 distinguished 36 genotypes in this study and was most informative in the study of Brunings et al. (2010) as well with the ability to distinguish 24 genotypes. The least informative primer pairs in this study were EMFax-381827 and EMFv-125 as both were able to distinguish only 12 genotypes.

Table 2. Characteristics of SSR (simple sequence repeat) loci

\begin{tabular}{cccccc}
\hline No. & SSR primer pair & $\begin{array}{c}\text { Allele size range } \\
\text { in bp }\end{array}$ & $\begin{array}{c}\text { Number of } \\
\text { alleles }\end{array}$ & $\begin{array}{c}\text { Number of } \\
\text { differentiated genotypes }\end{array}$ & $\begin{array}{c}\text { Genetic } \\
\text { diversity }\end{array}$ \\
\hline 1. & ARSFL-009 & $200-236$ & 20 & 38 & 0.37 \\
2. & ARSFL-010 & $214-268$ & 16 & 28 & 0.69 \\
3. & ARSFL-011 & $247-288$ & 17 & 31 & 0.42 \\
4. & EMFax-380097 & $146-183$ & 20 & 34 & 0.30 \\
5. & EMFax-381827 & $138-186$ & 12 & 12 & 0.35 \\
6. & EMFv-125 & $207-234$ & 10 & 12 & 0.33 \\
7. & EMFv-104 & $71-128$ & 21 & 36 & 0.25 \\
8. & CAFCT-084 & $105-147$ & 20 & 30 & 0.19 \\
9. & CAFCT-110 & $136-182$ & 20 & 32 & 0.26 \\
10. & CAFCT-103 & $117-151$ & 9 & 28 & 0.36 \\
11. & CAFCT-152 & $105-147$ & 16 & 38 & 0.19 \\
\hline \multicolumn{7}{r}{} & Mean & - & 16.5 & 29 & 0.34 \\
\hline
\end{tabular}

The genetic diversity among primer pairs varied from 0.19 (CFACT-084 and CFACT-152) to 0.69 (ARSFL-010), with an average of 0.34 . This indicates the conservativeness of non-coding regions in strawberry genome. According to the results obtained in this study, we agree with Dangl et al. (2007) suggestion to use the primer pairs ARSFL-009, ARSFL-010 and ARSFL-011 for cultivar identification.
AFLP analysis. A total of 1178 fragments were identified in 44 strawberry accessions using six AFLP primer combinations, of which 927 (78.7\%) were polymorphic. The fragment number generated with each AFLP primer combination varied between 112 and 237, with an average of 196 (Table 3).

The number of polymorphic fragments varied from 44 to 197 (154.5 on average). The highest number

Table 3. Number of fragments, number of polymorphic fragments and degree of polymorphism in our AFLP study of 44 strawberry cultivars and hybrid clones

\begin{tabular}{|c|c|c|c|c|c|}
\hline \multirow{2}{*}{ No. } & \multicolumn{2}{|c|}{ Primer combination } & \multirow{2}{*}{$\begin{array}{l}\text { Number of } \\
\text { fragments }\end{array}$} & \multirow{2}{*}{$\begin{array}{c}\text { Number of } \\
\text { polymorphic fragments }\end{array}$} & \multirow{2}{*}{$\begin{array}{c}\text { Polymorphism } \\
\%\end{array}$} \\
\hline & EcoRI & MseI & & & \\
\hline 1. & $\mathrm{ACT}$ & CAC & 172 & 129 & 75 \\
\hline 2. & AGG & CAA & 112 & 44 & 39 \\
\hline 3. & $\mathrm{ACC}$ & CAT & 237 & 191 & 81 \\
\hline 4. & $\mathrm{ACC}$ & CTA & 224 & 191 & 85 \\
\hline 5. & $\mathrm{ACC}$ & $\mathrm{CAC}$ & 223 & 197 & 88 \\
\hline 6. & $\mathrm{ACC}$ & $\mathrm{CAG}$ & 210 & 175 & 83 \\
\hline Mean & - & - & 196.3 & 154.5 & 75.2 \\
\hline
\end{tabular}

of polymorphic fragments (197) was generated using the EcoRI-AGG/MseI-CAC primer combination. The least polymorphic was the primer combination EcoRIAGG/MseI-CAA with 44 polymorphic fragments. The polymorphism rate among the six AFLP primer combinations varied between $39 \%$ and $88 \%$ (75.2\% on average). For strawberry accessions used in this study, the most informative was the EcoRI-ACC/MseI-CAC primer combination. The number of polymorphic fragments for primer combinations EcoRI-ACC/MseI-CAC and 
EcoRI-ACC/MseI-CAG was notably larger than in the previous study on strawberry (Degani et al., 2001). This may be due to the use of capillary electrophoresis in this study, which is a more sensitive method than gel electrophoresis.

Cluster analysis. For the investigation of genetic relationships among 44 strawberry genotypes, the common dendrogram using AFLP and SSR markers was constructed, due to the fact that the different DNA marker systems cover the different (sequence specifictagged and nonspecific) DNA segments of genome and enables a more comprehensive characterization of the genome as compared to the use of different marker systems separately. The assessed strawberry genotypes were clustered into two groups in the dendrogram (Fig.).
The first group contained 34 accessions of strawberry. The cv. 'Chelsea Pensioner' was separated from remaining accessions in this group (bootstrap value $74 \%$ ). Some of associations in this group could be explained according to the pedigree: the seedling clone 103301 is an offspring of cv. 'Lucy', the seedling clone 103801 is an offspring of L-181 and 'Venta Rvk' is the somaclonal variant of 'Venta'. The remaining associations (with the bootstrap value $\geq 50 \%$ ) were not related to pedigree in this group. It indicates the dependence of the analysis results on the type of markers and as well as of the number of markers used for the analysis. The second group of the dendrogram consisted of ten accessions, mostly of bred clones. Two separations in this group were indicated with high bootstrap values (96-100\%): the seedlings 080903

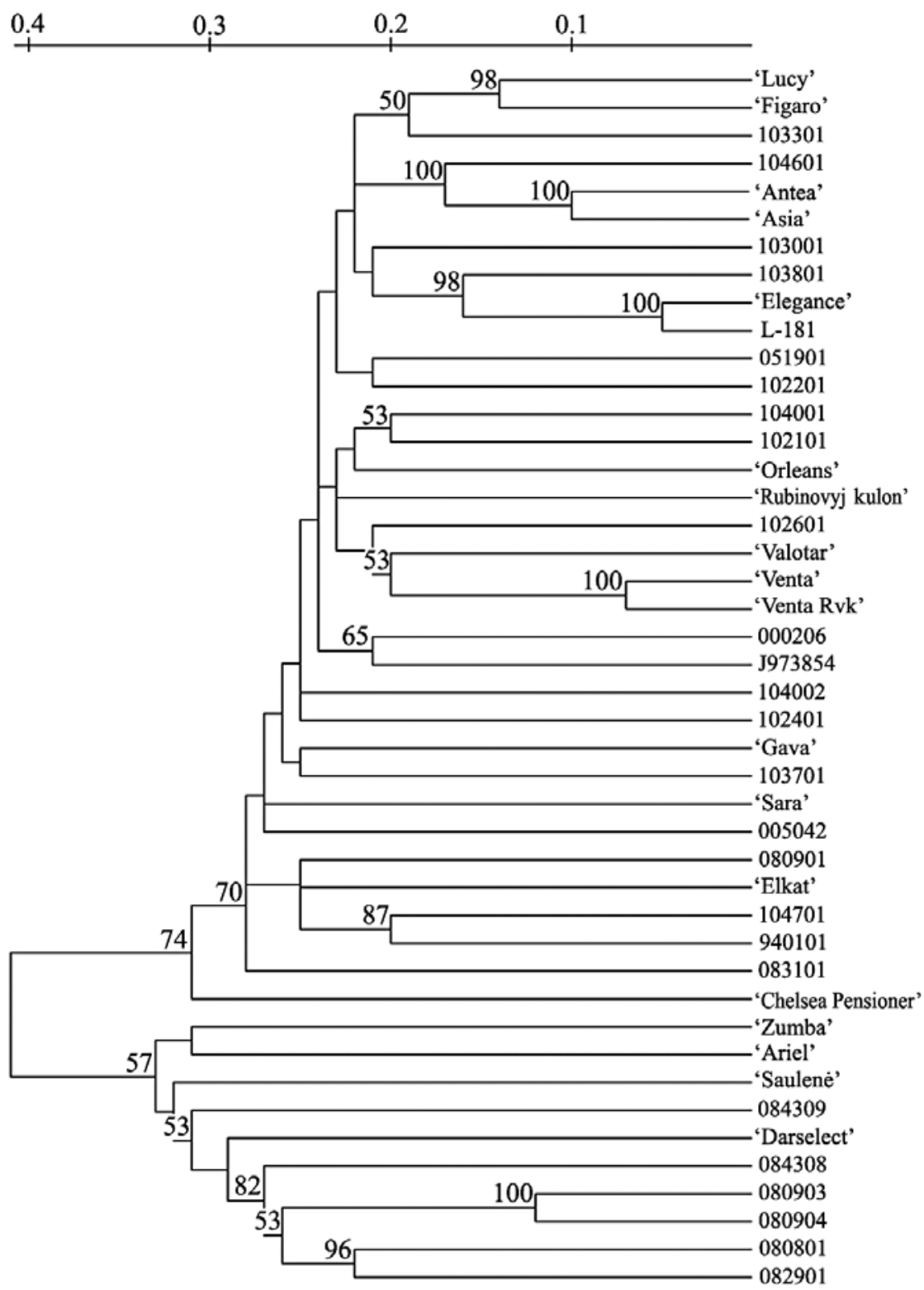

Notes. The numbers above the nodes of dendrogram indicate the bootstrap values of equal or greater than $50 \%$. The scale above the dendrogram indicates the distance level between accessions.

Figure. Cluster analysis of 44 strawberry accessions based on combined analysis of SSR (simple sequence repeat) and AFLP (amplified fragment length polymorphism) molecular markers 
and 080904 were separated together due to the same cross combination of common parents 'Venta' $\times$ 'Ariel' and two seedlings 080801 and 082901 - due to the common parent 'Irma'.

Genetic diversity of cultivated strawberry is quite low (Dale, Sjulin, 1990) and genetic affinities among hybrid clones are not unexpected. Although strawberries have complicated ploidy levels and different parentages, most of the alleles are shared among the cultivated strawberries (Yoon et al., 2012). The level of genetic diversity in strawberry germplasm is a critical consideration for the breeding of new cultivars. Inbreeding in cultivated strawberry leads to rapid loss of vigour, yield and fruit size. The gene pool of strawberry cultivars is narrow due to the intense selection for certain traits and the use of relative small number of parental forms. Determining the amount of genetic diversity available in germplasm has typically been estimated through pedigree analysis. However, inaccurate pedigree records, absence of pedigree records, or misnamed and/or renamed cultivars can confound the accuracy of such estimation (Degani et al., 2001). Cultivars often express remarkably similar phenotypes, especially in the vegetative stage. Moreover, discerning phenotypic descriptors may vary greatly with environmental conditions and cultural practices (Brunings et al., 2010). As molecular methods are not influenced by environment and therefore stable in any development stage, they provide information, which can be useful for increasing effectiveness of breeding and for performing purposeful plant genetic studies.

Our results show that combination of SSR and AFLP methods is effective and useful for identification of cultivars and for assessing the level of genetic diversity in strawberry cultivars and breeding lines.

\section{Conclusions}

1. The study identified SSR (simple sequence repeat) primer pairs ARSFL-009, CFACT-152 and EMFv-104, and AFLP (amplified fragment length polymorphism) primer combinations EcoRI-ACC/MseICAC and EcoRI-ACC/MseI-CTA as the most informative among the 44 strawberry cultivars and hybrid clones.

2. Cluster analysis of 44 strawberry accessions based on combined analysis of SSR and AFLP markers revealed two main groups consisting of 10 and 34 strawberry cultivars and clones. The combined analysis of 181 SSR and 1178 AFLP markers provided improved knowledge of genetic diversity of strawberry, developed in Lithuania.

\section{Acknowledgements}

The research was funded by the Research Council of Lithuania grant No. MIP-54/2013.

Received 23072014 Accepted 23022015

\section{References}

Agarwal M., Shrivastava N., Padh H. 2008. Advances in molecular marker techniques and their applications in plant sciences. Plant Cell Reports, 27: 617-631 http://dx.doi.org/10.1007/s00299-008-0507-z

Arnau G., Lallemand J., Bourgoin M. 2002. Fast and reliable strawberry cultivar identification using inter simple sequence repeat (ISSR) amplification. Euphytica, 129: 69-79

http://dx.doi.org/10.1023/A:1021509206584

Baniulis D., Gelvonauskienė D., Rugienius R., Sasnauskas A., Stanienė G., Stepulaitienė I., Frercks B., Sikorskaite S., Lukoševičiūtė V., Mažeikienė I., Šikšnianienė J. B., Morkūnaitè-Haimi Š., Haimi P., Bendokas V., Gelvonauskis B., Šikšnianas T., Stanys V. 2013. Orchard plant breeding, genetics, and biotechnology research at the Institute of Horticulture, LRCAF. Sodininkyste ir daržininkystè, 32 (3-4): 21-48

Bell J. A., Simpson D. W. 1994. The use of isoenzyme polymorphisms as an aid for cultivar identification in strawberry. Euphytica, 77: 113-117 http://dx.doi.org/10.1007/BF02551472

Brunings A. M., Moyer C., Peres N., Folta K. M. 2010. Implementation of simple sequence repeat markers to genotype Florida strawberry varieties. Euphytica, 173: $63-75$

http://dx.doi.org/10.1007/s10681-009-0112-4

Dale A., Sjulin T. M. 1990. Few cytoplasms contribute to North American strawberry cultivars. HortScience, 25: $1341-1342$

Dangl G. S., Lee E. W., Sim S. T., Golino D. A. 2007. A new system for strawberry cultivar identification developed at foundation plant services (FPS), University of California, Davis, using simple sequence repeat (SSR) primers. NASS / NASGA proceedings, p. 118-121

Degani C., Rowland L. J., Saunders J. A., Hokanson S. C., Odgen E. L., Golan-Goldhirsh A., Galleta G. J. 2001. A comparison of genetic relationship measures in strawberry (Fragaria $\times$ ananassa Duch.) based on AFLPs, RAPDs, and pedigree data. Euphytica, 117: 1-12 http://dx.doi.org/10.1023/A:1004008408435

Doyle J. J., Doyle J. L. 1990. Isolation of plant DNA from fresh tissue. Focus, 12 (1): 13-15

Frercks B., Stepulaitienė I., Šikšnianienè J. B., Stanys V. 2013. Assessment of AFLP markers linked to fungal diseases and to spring frost resistance in sour cherry. Proceedings of the $6^{\text {th }}$ international scientific conference Rural Development 2013, 6 (2), p. 84-88

Frercks B., Stanys V., Siksnianiene J. B., Stepulaitiene I., Gelvonauskiene D., Staniene G., Rugienius R., Siksnianas T. 2014. Efficiency of AFLP marker attributes in the genetic analysis of sweet cherry cultivars. Journal of Food, Agriculture and Environment, 12 (1): 122-127

Gil-Ariza D. J., Amaya I., Botella M. A., Muñoz Blanco J., Caballero J. L., López-Aranda J. M., Valpuesta V., Sánchez-Sevilla J. F. 2006. EST-derived polymorphic microsatellites from cultivated strawberry (Fragaria $\times$ ananassa) are useful for diversity studies and varietal identification among Fragaria species. Molecular Ecology Notes, 6 (4): 1195-1197

http://dx.doi.org/10.1111/j.1471-8286.2006.01489.x 
Govan C. I., Simpson D. W., Johnson A. W., Tobutt K. R., Sargent D. J. 2008. A reliable multiplexed microsatellite set for genotyping Fragaria and its use in a survey of $60 \mathrm{~F} . \times$ ananassa cultivars. Molecular Breeding, 22 (4): 649-661 http://dx.doi.org/10.1007/s11032-008-9206-2

Hall B. G. 2008. Phylogenetic trees made easy: a how-to manual ( $3^{\text {rd }}$ ed.)

Honjo M., Nunome T., Kataoka S., Yano T., Yamazaki H., Hamano M., Yui S., Morishita M. 2011. Strawberry cultivar identification based on hypervariable SSR markers. Breeding Science, 61 (4): 420-425 http://dx.doi.org/10.1270/jsbbs.61.420

Lewers K. S., Styan S. M. N., Hokanson S. C. 2005. Strawberry GenBank-derived and genomic simple sequence repeat (SSR) markers and their utility with strawberry, blackberry, and red and black raspberry. Journal of the American Society for Horticultural Science, 130 (1): 102-115

Lörz H., Wenzel G. 2005. Molecular marker systems in plant breeding and crop improvement. New York, USA http://dx.doi.org/10.1007/b137756

Meudt H. M., Clarke A. C. 2007. Almost forgotten or latest practice? AFLP applications, analyses and advances. Trends in Plant Science, 12 (3): 106-117 http://dx.doi.org/10.1016/j.tplants.2007.02.001

Milella L., Saluzzi D., Lapelosa M., Bertino G., Spada P., Greco I., Martelli G. 2006. Relationships between an Italian strawberry ecotype and its ancestor using RAPD markers. Genetic Resources and Crop Evolution, 53: 1715-1720 http://dx.doi.org/10.1007/s10722-005-1405-7

Rousseau-Gueutin M., Gaston A., Aïnouche A., Aïnouche M. L., Olbricht K., Staudt G., Richard L., Denoyes-Rothan B. 2009. Tracking the evolutionary history of polyploidy in Fragaria L. (strawberry): new insights from phylogenetic analyses of low-copy nuclear genes. Molecular Phylogenetics and Evolution, 51 (3): 515-530 http://dx.doi.org/10.1016/j.ympev.2008.12.024

Rugienius R., Sasnauskas A., Shikshnianas T. 2004. 'Saulene' and 'Dange' - two recent Lithuanian strawberry cultivars. Acta Horticulturae, 649: 73-76

Rugienius R., Blažytė A., Lukoševičiūtè V., Šikšnianienė J. B., Frercks B., Gelvonauskiené D., Gelvonauskis B., Sasnauskas A., Baniulis D., Stanys V. 2013. Genetic polymorphism of wild pear accessions collected in Lithuania. Baltic Forestry, 19 (1): 13-21

Sargent D. J., Clarke J., Simpson D. W., Tobutt K. R., Arus P., Monfort A., Vilanova S., Denoyes-Rothan B., Rousseau M., Folta K. M., Bassil N. V., Battey N. H. 2006. An enhanced microsatellite map of diploid Fragaria. Theoretical and Applied Genetics, 112 (7): 1349-1359 http://dx.doi.org/10.1007/s00122-006-0237-y

Sargent D., Cipriani G., Vilanova S., Gil-Ariza D., Arus P., Simpson D. W., Tobutt K. R., Monfort A. 2008. The development of a bin mapping population and the selective mapping of 103 markers in the diploid Fragaria reference map. Genome, 51 (2): 120-127 http://dx.doi.org/10.1139/G07-107

Stanys V., Baniulis D., Morkunaite-Haimi S., Siksnianiene J. B., Frercks B., Gelvonauskiene D., Stepulaitiene I., Staniene G., Siksnianas T. 2012. Characterising the genetic diversity of Lithuanian sweet cherry (Prunus avium L.) cultivars usisng SSR markers. Scientia Horticulturae, 142: 136-142 http://dx.doi.org/10.1016/j.scienta.2012.05.011
Van de Peer Y., De Wachter R. 1994. TREECON for Windows: a software package for the construction and drawing of evolutionary trees for the Microsoft Windows environment. Computer Applications Biosciences, 10: 569-570 http://dx.doi.org/10.1093/bioinformatics/10.5.569

Vos P., Hogers R., Bleeker M., Reijans M., van de Lee T., Hornes M., Frijters A., Pot J., Peleman J., Kuiper M., Zabeau M. 1995. AFLP: a new technique for DNA fingerprinting. Nucleic Acids Research, 23 (21): $4407-4414$ http://dx.doi.org/10.1093/nar/23.21.4407

Yoon M. Y., Moe K. T. Kim D. Y., Rho I. R., Kim S., Kim K. T., Won M. K., Chung J. W., Park Y. J. 2012. Genetic diversity and population structure analysis of strawberry (Fragaria $\times$ ananassa Duch.) using SSR markers. Electronic Journal of Biotechnology, 115 (2): 1-16 
ISSN 1392-3196 / e-ISSN 2335-8947

Zemdirbyste-Agriculture, vol. 102, No. 2 (2015), p. 177-184

DOI $10.13080 /$ z-a.2015.102.023

\title{
Daržinės braškès (Fragaria $\times$ ananassa Duch.) veislių ir hibridinių klonų apibūdinimas naudojant PPS bei PFIP molekulinius žymeklius
}

\author{
R. Rugienius ${ }^{1}$, J. B. Šikšnianienè ${ }^{1}$, B. Frercks ${ }^{1}$, G. Staniené $\dot{e}^{1}$ I. Stepulaitiené $\dot{1}^{1}$ \\ P. Haimi ${ }^{1}$, V. Stanys ${ }^{1,2}$ \\ ${ }^{1}$ Lietuvos agrarinių ir miškų mokslų centro Sodininkystès ir daržininkystès institutas \\ ${ }^{2}$ Aleksandro Stulginskio universitetas
}

\section{Santrauka}

Atliekant genetinius ir selekcinius tyrimus, paprastų pasikartojančių sekų (PPS) ir pagausintų fragmentų ilgio polimorfizmo (PFIP) žymekliai plačiai naudojami dẻl savo daugiaaleliškumo, gausumo, atsikartojamumo ir plataus genomo padengimo. Straipsnyje pateiktas daržinès braškès (Fragaria $\times$ ananassa Duch.) 44 skirtingu genotipų genetinis apibūdinimas naudojant PPS ir PFIP molekulinius žymeklius. Braškès veislių ir hibridinių klonų, kurių daugelis yra sukurti Lietuvos agrarinių ir miškų mokslų centro Sodininkystès ir daržininkystės institute, genetinė ịvairovė ịvertinta naudojant 11 anksčiau paskelbtų PPS pradmenų porų ir 6 PFIP pradmenų kombinacijas. PPS multipleksinès analizès duomenimis, kiekvienai pradmenų porai identifikuota nuo 9 iki 21 alelių. Diferencijuotų genotipų skaičius svyravo nuo 12 iki 38. PPS pradmenų poros ARSFL-009, CFACT-152 ir EMFv-104 buvo pačios informatyviausios. Tiriant PFIP polimorfinių fragmentų skaičius varijavo nuo 44 iki 197. Polimorfinių fragmentų dažnis svyravo nuo 39 \% (pradmenų kombinacija EcoRI-AGG/MseI-CAA) iki $88 \%$ (EcoRI-ACC/MseI-CAC). Tyrimo rezultatai rodo, kad pasirinkti anksčiau publikuoti mikrosatelitiniai pradmenys ir atrinktos didelio polimorfiškumo PFIP pradmenų kombinacijos po pirminès atrankos yra tinkami genotipuoti braškès pavyzdžius. Siekiant gauti išsamų tirtų braškès genotipų genetinių ryšių aprašymą, buvo panaudoti DNR fragmentai, išskirti taikant abi žymeklių sistemas. Klasterinė analizė atskleidè dvi pagrindines genotipų grupes, kurias sudaro atitinkamai 10 ir 34 braškès veislès ir klonai.

Reikšminiai žodžiai: daržinė braškè, genetine ̨ivairovè, genotipavimas, hibridai, pagausintų fragmentų ilgio polimorfizmas, paprastos pasikartojančios sekos. 